\title{
DOES ELECTION IMPACT ON STOCK MARKET RETURNS IN BANGLADESH?
}

\author{
Gourav Roy \\ MBA Graduate \\ Department of Finance \\ University of Dhaka \\ Dhaka, Bangladesh \\ E-mail: gouravroy.du@gmail.com \\ Md Atiqullah Khan \\ MBA Graduate \\ Department of Finance \\ University of Dhaka \\ Dhaka, Bangladesh \\ E-mail: writetoatiq@gmail.com
}

\begin{abstract}
This paper investigates the impact of parliamentary general election on the stock market returns by considering the previous fifteen days and the after fifteen days of each of six elections in Bangladesh held between 1991 and 2018. The study analyzed the election effect on stock returns through considering both abnormal returns by choosing 20 stocks as a proxy of portfolio motive of the investors and the broad index returns as a measurement of whole market scenario. The study employed descriptive statistics, $t$-tests, and F-tests to understand the impact of election by gauging the changes in return series. Descriptive statistics showed very high differences in means, standard deviations, and volatilities. Paired t-tests showed significant differences between the means and F-tests showed significant differences between the variances of the returns during before and after days of these elections. The results were the same for abnormal returns and broad index returns. The impacts of individual election on the returns were also found as the same in most cases. The study has found some very useful insights part of which can benefit the policymakers to reform the policies. The common investors and the financial market participants can also make better investment plan.
\end{abstract}

Keywords: Election, Event study, Stock returns, DSE, Bangladesh.

JEL Classification Codes: D72, G14, P48.

\section{INTRODUCTION}

Stock market is considered as the mirror of the economy of a country (Jensen, Mercer \& Johnson, 1996). The growth of the stock market is also an evidence of economic progress of a country. The stock market determines how capital is formulating in the veins of a nation. Thus, the fluctuation or volatility of a stock market means a big thing to be concerned of for the 
investors, government, and common people as well. Different economic and non-economic factors impact on it. Different political forces and political shifts play as very important factors for almost all the stock markets.

The political events determine what will be the economic changes in the country for the future and the present. With this consideration, the parliamentary general election is a highly noticeable event that can highly impact on an economy including the stock market performance. Bangladesh is a country with having the total GDP of USD 313 billion (Haroon, 2020). Dhaka Stock Exchange (DSE) is the major stock exchange of Bangladesh with having over 383 companies and several bonds listed on it. The total market capitalization of it is about USD 59.32 billion (The Financial Express, 2021). As like other stock markets around the world, stock market of Bangladesh also gets influenced by different forces.

As Bangladesh is a very politically indulged country and the economic decisions and financial activities are highly influenced by political decisions and structural planning of ruling government, so does the base of the study get motivation to dig a hole to know the impact of election on the stock market performances of Bangladesh. From the aspect of Bangladesh, the relation of stock market volatility with the election movements and events can also have strong correlations.

Surely, it requires a high level of investigation to know whether there exists any relation between stock market returns and general election in Bangladesh. If it exists, then what the directions are that actually follow. Moreover, the investors are not properly aware of the growth stocks and value stocks and the political momentum with respect to these types of stocks.

As the general elections determine who will be in governance for the next five years, the common investors and financial market participants always try to take a safe position before the general election. Sometimes the herd instinct of the investors makes the market too much volatile and also makes it go up too much imprudently or go down too much drastically. Thus, the background of the study is fully concentrated on analyzing the relationship between parliamentary general elections and stock market returns. This paper aims at fulfilling these objectives:

- To understand whether there exists any relationship between parliamentary general election and stock market returns in Bangladesh.

- To inform the common investors, financial market participants, and researchers about the election effect on the stock market returns of Bangladesh.

The study incorporates the information for 29 years (1991-2018) to determine the election effect on the market performances. Dhaka Stock Exchange (DSE) has been considered as the proxy of stock exchanges in Bangladesh to avoid any repetitive information in the study. For structuring the data, the event window has been considered as the election date and the estimation window has been considered as the 15 days before the election and 15 days after the election as per the Market Model (MacKinlay, 1997) and the necessary key techniques of some steps that have been guided by (Kabiru, Ochieng, \& Kinyua, 2015).

The study has some limitations. The findings are based on historical information and not progressive in reality. There is no concrete evidence that the result of the study has the possibility of repetition in future. Due to the incongruence of data, 2001 election wasn't taken into consideration in this study. Even though existence of these limitations, the study is believed to control the other corners to legitimately represent the accurate view of the implementation of the purpose of the study. 
The studies and the findings conducted in previous researches are described in second part of this paper. The third part of the paper discusses about the data and methodology of the studies. The fourth part discusses about the analysis and findings and the last part includes conclusion and policy recommendations. Thus this paper completes the investigation of the impact of parliamentary election on stock market returns in Bangladesh.

\section{REVIEW OF LITERATURE}

There prevail some previous studies to understand the impact of general election on stock market performance. Some of the relevant literature reviews are discussed below:

Niederhoffer, Gibbs and Bullock (1970) examined the stock market actions by considering the before and after the days and months of US presidential general elections to find out the connections between US political events and the US stock market movements which created many investigations and interests. Later, Jensen, Mercer \& Johnson (1996) stated that the stock market gets influenced by the common investors' behavior and trading strategies which are also influenced by the economic and political changes that take place in the country.

Foerster and Schmitz (1997) in their study tried to focus on the US parliamentary general election cycles where there existed a concrete relation between stock markets and political event like PGE. The study not only covered the US stock markets but also covered the OECD countries. In this study, total 18 countries were considered and the spectrum of the study was from 1957 to 1966 . The study showed that the pattern was existent between the variables. But the expectation that US stock markets would be mostly affected by this parliamentary general election and the other OECD countries would not be affected significantly was not true. The hypothesis was rejected in the sense that both the US countries and the OECD countries had similar sort of significance with respect to the parliamentary general election.

Pantzalis, Stangeland, and Turtle (2000) tried to show some scrutiny on the stock market performance moving around the parliamentary general election on a national level and international scale of 33 countries and discovered that the criteria of Index Abnormal Returns (IARs) are usually having a significantly differentiating outcome near the fifteen days plus and minus the event. Booth and Booth (2003) analyzed the presidential mystery to advantage small capitalized stocks, where no noteworthy variance between the returns of large capitalized stocks during the regimes of both democratic and republican presidents.

At the same time, Santa-Clara and Valkanov (2003) tried to find out some linkage between US parliamentary general election and US stock market movements. They focused on the study in a different angle from the previous researches. They focused on the capitalization of stocks and how the large and small stocks did perform under the event of parliamentary general election. They found that the large capitalized shares tended to perform better when the government of USA was taken over by the democratic parties. It has been seen that large-cap stocks and securities tended to get a $7 \%$ better result under the Democratic Parties of US. But the small stocks tended to get a better result of $22 \%$ than the normal cases under the Republican Parties.

Later, Anderson, Malone \& Marshall (2008) distinguished that the political impacts of USA are not as easy as it can be for other countries. The impacts and consequences are quite complicated. The governmental and political finance during the PGE is not clearly exposed in USA. That is why the common investors solely depend on the expansionary goals of the political candidates of USA and based on that they tend to take decisions where to invest and where to not. 
Bialkowski, Gottschalk, and Wisniewski (2007) studied a case including 27 countries who were the members of OECD in which they tried to show some relation of national elections tempting to higher stock market volatility. Their experimental outcome of the research shows that investors (institutional and financial market participants) are still astounded by the ultimate casting of votes. Stock prices tend to react powerfully in response of this astonishment and momentarily raised levels of uncertainty.

Irungu (2012) examined the stock data elements of parliamentary general election consequences under the announcement at the Nairobi securities exchange by means of the methodologies used in events study for the ten year periods from 1997 to 2007 and instituted that the CARs (Cumulatively Abnormal Returns) showed a dropping trend or function of movement in the periods before the announcement and a slower or a medium pattern increase after the event happening announcement representing to market receiving and reacting to the information in the investors' confidence and stability in political balance.

Menge, Mwangi, and Kimani (2014) detailed the outcome of parliamentary general election on stock market yields at the Nairobi Securities Exchange (NSE) implementing the methodology of the events studies that covered an eleven year periods from 2002 to 2013 which established the fact that that actual returns using the return series formula were pointedly higher before the event of elections but not so much higher after the event of election periods. The assumptions made out of the consequences that the expected returns as well as the market returns tend to show a specific movements of increase before the election but decrease or remain stagnant after the election. Here is the list of the findings of some studies regarding the research:

Table 1. Evidences that Found Link between Elections and Stock Market Movements

\begin{tabular}{|l|l|l|l|c|}
\hline \multicolumn{1}{|c|}{ Event } & $\begin{array}{l}\text { Researched } \\
\text { by }\end{array}$ & \multicolumn{1}{|c|}{$\begin{array}{c}\text { Impact on Stock } \\
\text { Market before the } \\
\text { Event }\end{array}$} & $\begin{array}{c}\text { Impact on Stock } \\
\text { Market after the } \\
\text { Event }\end{array}$ & $\begin{array}{c}\text { Existence } \\
\text { of } \\
\text { Relation }\end{array}$ \\
\hline $\begin{array}{l}\text { UK GE* } \\
\text { UK }\end{array}$ & $\begin{array}{l}\text { Lehander } \\
\text { and } \\
\text { Lönnqvist } \\
(2011)\end{array}$ & $\begin{array}{l}\text { British Telecom share } \\
\text { price fell sharply. }\end{array}$ & $\begin{array}{l}\text { British Telecom } \\
\text { share price moved up } \\
\text { sharply. }\end{array}$ & Existent \\
\hline $\begin{array}{l}\text { Ten } \\
\text { developed } \\
\text { countries' }\end{array}$ & $\begin{array}{l}\text { Niederhoffer, } \\
\text { Gibbs and } \\
\text { Bullock } \\
\text { (1970), Peel } \\
\text { and Pope } \\
(1993) \text { and } \\
\text { Gemmil } \\
\text { (1992) }\end{array}$ & $\begin{array}{l}\text { The broad index goes } \\
\text { down before the } \\
\text { election. }\end{array}$ & $\begin{array}{l}\text { The Broad Index } \\
\text { went up after the } \\
\text { election. }\end{array}$ & Existent \\
\hline GEs of USA & $\begin{array}{l}\text { Booth and } \\
\text { Booth (2003) }\end{array}$ & $\begin{array}{l}\text { The small stocks } \\
\text { underperformed before } \\
\text { election }\end{array}$ & $\begin{array}{l}\text { The small stocks } \\
\text { over performed after } \\
\text { elections }\end{array}$ & Existent \\
\hline GEs of USA & $\begin{array}{l}\text { Hensel and } \\
\text { Ziemba } \\
\text { (1995), }\end{array}$ & $\begin{array}{l}\text { The large stock in USA } \\
\text { had almost no impact } \\
\text { before election }\end{array}$ & $\begin{array}{l}\text { The large stock in } \\
\text { USA had almost no } \\
\text { impact after election }\end{array}$ & $\begin{array}{l}\text { Non- } \\
\text { Existent }\end{array}$ \\
\hline
\end{tabular}




\begin{tabular}{|c|c|c|c|c|}
\hline GEs of USA & $\begin{array}{l}\text { Santa-Clara } \\
\text { and } \\
\text { Valkanov } \\
(2003)\end{array}$ & $\begin{array}{l}\text { The large stocks } \\
\text { performed better in } \\
\text { democratic presidency }\end{array}$ & $\begin{array}{l}\text { The large stocks } \\
\text { performed better than } \\
\text { before when } \\
\text { democratic } \\
\text { presidency continued }\end{array}$ & Existent \\
\hline $\begin{array}{l}\text { GEs of USA } \\
\text { and impact on } \\
18 \text { OECD } \\
\text { Countries }\end{array}$ & $\begin{array}{l}\text { Foerster and } \\
\text { Schmitz } \\
(1997)\end{array}$ & $\begin{array}{l}\text { There were huge } \\
\text { downfall before } \\
\text { presidency election in } \\
\text { these eighteen countries' } \\
\text { stock exchanges }\end{array}$ & $\begin{array}{l}\text { Whether the stock } \\
\text { index will go up or } \\
\text { down depended on } \\
\text { who is going to chair } \\
\text { the presidency of } \\
\text { USA }\end{array}$ & Existent \\
\hline $\begin{array}{l}\text { Study on } \\
\text { New Zealand } \\
\text { stock market } \\
\text { due to GE. }\end{array}$ & $\begin{array}{l}\text { Cahan et al., } \\
(2005)\end{array}$ & $\begin{array}{l}\text { Broad index goes up } \\
\text { generally before election }\end{array}$ & $\begin{array}{l}\text { Broad Index goes } \\
\text { down }\end{array}$ & Existent \\
\hline $\begin{array}{l}27 \text { OECD } \\
\text { Countries' } \\
\text { GEs and their } \\
\text { respective } \\
\text { stock } \\
\text { exchanges }\end{array}$ & $\begin{array}{l}\text { Bialkowski, } \\
\text { Gottschalk } \\
\text { and } \\
\text { Wisniewski } \\
(2007)\end{array}$ & $\begin{array}{l}\text { Huge volatility among } \\
\text { stocks; some move up } \\
\text { and some down }\end{array}$ & $\begin{array}{l}\text { The stocks related to } \\
\text { government } \\
\text { financing tended to } \\
\text { move up while the } \\
\text { others faced negative } \\
\text { changes }\end{array}$ & Existent \\
\hline $\begin{array}{l}\text { Belgium's } \\
\text { GE }\end{array}$ & $\begin{array}{l}\text { Vuchelen } \\
\text { (2003) }\end{array}$ & $\begin{array}{l}\text { Huge volatility among } \\
\text { stocks; some move up } \\
\text { and some down }\end{array}$ & $\begin{array}{l}\text { The volatility tends } \\
\text { to continue even after } \\
\text { one month }\end{array}$ & Existent \\
\hline Taiwan GE & Hung (2011) & Election cycle exists & $\begin{array}{l}\text { Fluctuation occurs } \\
\text { after election }\end{array}$ & Existent \\
\hline $\begin{array}{l}\text { Nairobi Stock } \\
\text { Exchange and } \\
\text { GE in Kenya }\end{array}$ & $\begin{array}{l}\text { Irungu } \\
(2012)\end{array}$ & Stock index falls & Stock Index rises & Existent \\
\hline $\begin{array}{l}\text { A study } \\
\text { covering ten } \\
\text { recent years } \\
\text { tenure on } \\
\text { Kenya }\end{array}$ & $\begin{array}{l}\text { Menge, } \\
\text { Mwangi and } \\
\text { Kimani } \\
\text { (2014) }\end{array}$ & $\begin{array}{l}\text { Some selected twenty } \\
\text { stocks had upward trend } \\
\text { in returns }\end{array}$ & $\begin{array}{l}\text { Some selected } \\
\text { twenty stocks had } \\
\text { downward trend in } \\
\text { returns. It was found } \\
\text { of political finance } \\
\text { involvement. }\end{array}$ & Existent \\
\hline
\end{tabular}

Note. *GE stands for General Election

The Table 1 shows that the research findings of the previous studies. In the above table, almost all of the relevant researches on the same interest fields have been discussed with their findings. It is seen that almost in every study the impact of general election on stock market movement is existent. But whether stock prices or, index returns will go up or down before or after the election was not determined. It's evident that the impact of general election on stock market returns is existent.

There has been so many researches that have been done on many countries including the USA, New Zealand, Kenya, Taiwan, UK, Belgium, European countries etc. But such types of 
valuable and necessary analysis was yet to be institutionalized and published so far from the context of Bangladesh. Again, no such study has been done before that incorporated both the abnormal returns and the index returns separately to analyze both the portfolio and index based relationship analysis in this aspect. Thus, this paper has been designed to complete this research gap.

\section{Data}

\section{DATA AND METHODOLOGY}

The study required stock price data and broad index data for the period of 1991-2019 which were collected from Dhaka Stock Exchange website ("Dhaka Stock Exchange", 2019). For the analysis of data, MS Excel and Stata software were used.

\section{Methodology}

To understand the impacts of election on stock market returns in Bangladesh, this research followed the perspective of the motive of general investors and the perspective of whole stock market scenario. The research fully concentrated on event studies and thus the research followed the methodologies of event studies. The study followed these steps for analyzing the data:

\section{Step 1: Identification of event interest and event window}

The study considered six out of seven parliamentary general elections held in Bangladesh during 1991 to 2018 to discover something not investigated before. The Table 2 given below summarized the elections and the event windows:

Table 2. The Data Structure of the Event and Estimation Period for the Study

\begin{tabular}{|c|c|c|c|c|c|}
\hline Election & $\begin{array}{c}\text { Pre-event } \\
\text { window }\end{array}$ & Event date & $\begin{array}{c}\text { Post-event } \\
\text { window }\end{array}$ & Old govt. & New govt. \\
\hline 1991 & before 15 days & 27 February, 1991 & after 15 days & JP & BNP \\
\hline $1996 \mathrm{a}$ & before 15 days & 15 February, 1996 & after 15 days & BNP & BNP \\
\hline $1996 \mathrm{~b}$ & before 15 days & 12 June, 1996 & after 15 days & BNP & BDAL \\
\hline 2008 & before 15 days & 29 December, 2008 & after 15 days & BNP & BDAL \\
\hline 2014 & before 15 days & 5 January, 2014 & after 15 days & BDAL & BDAL \\
\hline 2018 & before 15 days & 30 December, 2018 & after 15 days & BDAL & BDAL \\
\hline
\end{tabular}

Note: Here, JP, BNP, and BDAL stand for Jatiya Party, Bangladesh Nationalist Party, and Bangladesh Awami League respectively

\section{Step 2: Selection of the firms for constructing investment portfolio}

The study on analyzing the impact of general elections on the abnormal returns of stock market of Bangladesh required to select some stocks listed on DSE from portfolio perspective that could replicate the stock market from 1991 to 2018. To meet this purpose, the proper selection of the stocks was very crucial to get in on a particular to the accurate results. 
Table 3. List of Chosen 20 stocks form Diversified Industries

\begin{tabular}{|l|c|c|}
\hline \multicolumn{1}{|c|}{ Name of the Stock } & Respective Industry & $\begin{array}{c}\text { Listing } \\
\text { Year }\end{array}$ \\
\hline 01. Eastern Cables Limited & Engineering & 1986 \\
\hline 02. Monno Ceramics Industries Limited & Ceramics & 1983 \\
\hline 03. Investment Corporation of Bangladesh & NBFIs & 1977 \\
\hline 04. United Insurance Limited & Insurance & 1990 \\
\hline 05. Padma Oil Company Limited & Fuel \& Power & 1976 \\
\hline 06. Bata Shoe Company (Bangladesh) Limited & Tannery & 1985 \\
\hline 07. Sonali Aansh Industries Limited & Cement & 1985 \\
\hline 08. Heidelberg Cement Bangladesh Limited & Textiles & 1989 \\
\hline 09. Stylecraft Limited & Food and Allied & 1983 \\
\hline 10. Olympic Industries Limited & Food and Allied & 1989 \\
\hline 11. National Tea Company Limited & Pharmaceuticals and Chemicals & 1979 \\
\hline 12. Beximco Pharmaceuticals Limited & Pharmaceuticals and Chemicals & 1986 \\
\hline 13. Ambee Pharmaceuticals Limited & Pharmaceuticals and Chemicals & 1988 \\
\hline $\begin{array}{l}\text { 14. Kohinoor Chemicals Company (Bangladesh) } \\
\text { Limited }\end{array}$ & & 1986 \\
\hline 15. The City Bank Limited & Banking & 1984 \\
\hline 16. Uttara Bank Limited & Banking & 1986 \\
\hline 17. United Commercial Bank Limited & Banking & 1987 \\
\hline 18. Usmania Glass Sheet Factory Limited & Miscellaneous & 1986 \\
\hline 19. GQ Ball Pen Industries Limited & Miscellaneous & 1989 \\
\hline $\begin{array}{l}\text { 20. Bangladesh Export Import Company Limited } \\
\text { (BEXIMCO) }\end{array}$ & Miscellaneous & \\
\hline
\end{tabular}

The Table 3 shows the 20 stocks chosen from respective industries. The selected stocks were having their smooth existence from 1991 to 2018 so that the study could get enough data of the stock prices, dividends, right shares, splits, and bonus shares.

\section{Step 3: Adjustment of the price data}

To make the data authentic and free from different types of biasness, all the price data of these 20 stocks were adjusted as per cash dividends, stock splits, bonus share issue, right share issue, capital gains etc.

\section{Step 4: Calculation of total actual returns}

After that, the study computed the changes recorded in share prices to determine the actual return as per following formula: 
Where, $P_{t}=$ The Price of a stock $\mathrm{i}$ in day $\mathrm{t}$; and, $P_{t-1}=$ The Price of stock $\mathrm{i}$ at previous trading day $(\mathrm{t}-1)$.

Thus, total actual returns were calculated by summing all the returns from these 20 stocks through using this formula:

Total Actual Returns in day t, $T A c R_{t}=(A c R 1 t+A c R 2 t+A c R 3 t+\ldots \ldots \ldots \ldots \ldots \ldots+A c R 20 t)$

Step 5: Calculation of market return series of broad index

DSEX, the broad index of Dhaka Stock Exchange, has been chosen as a proxy of whole stock market. The return series of DSEX for 15 trading days before and 15 trading days after of each election have been calculated and used for testing the hypotheses to get the broad picture in case the analysis of abnormal returns fails to replicate the stock movements due to national election. The changes in the DSEX index for each day were computed denoted as the whole market return or index return as per following formula:

Index Returns in day $\mathrm{t}, I R_{t}=\left[\left(D_{S E X}-D S E X_{t-1}\right) / D S E X_{t-1}\right]$

Here, $D S E X_{t}=$ the DSEX index in trading day $\mathrm{t}$; And, DSEXt-1 $=$ the DSEX index in previous trading day $(\mathrm{t}-1)$.

\section{Step 6: Calculating Abnormal Returns}

The research applied the formula to get abnormal returns:

Abnormal Returns, $A R_{t}=\left(T A c R_{t}-I R_{t}\right)$

\section{Step 7: Calculation of Cumulative Abnormal Returns and Cumulative Index returns}

The cumulative return based analysis was carried on to move the discussion to ultimate culmination of result to inform how the general election has impact on the stock market movements from the aspect of Bangladesh. Thus, CARs (Cumulative Abnormal Returns) and Cumulative Index Returns (CIRs) were also calculated for farther analysis and graphical representations. Here, CARs and CIRs show the reaction of the investors before and immediately after the election event. The total 30-day CARs and CIRs provide a clear understanding of the market response for the election. The CARs and CIRs for each day were calculated as per following formulae:

$$
\text { Here, } C A R_{t}=\Sigma A R_{t}
$$

Where, $C A R_{t}$ is the Cumulative Abnormal Returns in day $t$.

And, $C I R_{t}=\Sigma A R_{t}$

Where, CIR $t$ is the Cumulative Index Returns in day $t$. 


\section{Testing the Hypotheses and Models of the Study}

For the overall statistical techniques and their application and interpretation of the study, the following hypothesis hold for the entire study:

$\mathrm{H}_{0}$ : There exists no relationship between the election and stock market returns.

$\mathrm{H}_{1}$ : There exists relationship between the election and stock market returns.

In this step, three statistical techniques that have been used to apply with their respective hypotheses to prove the main hypothesis of the study and these are:

Descriptive Statistics: The descriptive statistics helps to find out the essential information about the means, standard deviation, minimum and maximum of dataset. This information is necessary to know the ranges, volatility levels, and fluctuation extents of the return series data for both before and after the elections to compare the differences.

Paired t-Tests: The paired t-test helps to test the hypothesis that whether there exists any significant difference between the means of the datasets of before and after the elections. For this t-test, the hypotheses are:

$\mathrm{H}_{0}$ : There exists no difference between the means of before election datasets and after election datasets.

$\mathrm{H}_{1}$ : There exists difference between the means of before election datasets and after election datasets.

F-Tests: In this study, F-test has been used for checking the hypothesis of finding if there exists any significant difference between the variances of the data sets. If the hypothesis is proved, it can be concluded that there exists a relation between election and stock market returns. The hypotheses are:

$\mathrm{H}_{0}$ : There exists no difference between the variances of the before election datasets and after election datasets.

$\mathrm{H}_{1}$ : There exists difference between the variances of the before election datasets and after election datasets.

With $90 \%$ confidence interval, all of the datasets for both individual election and altogether are to be statistically tested to get to the ultimate decision with holding the hypothesis.

\section{ANALYSIS AND FINDINGS}

This part of analysis has completely focused on the findings received through analyzing the data of abnormal returns and index returns. All the analysis was carried on to move the discussion to ultimate culmination of result to inform how the general election has impact on the stock market returns from the aspect of Bangladesh.

\section{Descriptive Statistics}

The descriptive statistics of the abnormal returns shown on Table 4 indicate that differences between the means of the returns of before and after each election are very high, the standard 
deviations of the abnormal returns in case of the after elections are higher than the abnormal returns of before elections in most cases. The minimum and maximum values have huge differences representing high volatilities due to election effects.

Table 4. Descriptive Statistics of the Abnormal Returns

\begin{tabular}{|c|c|c|c|c|c|c|c|c|c|}
\hline \multirow{2}{*}{ Election } & \multirow{2}{*}{ Obs } & \multicolumn{2}{|c|}{ Mean } & \multicolumn{2}{c|}{$\begin{array}{c}\text { Standard } \\
\text { Deviation }\end{array}$} & \multicolumn{2}{c|}{ Minimum } & \multicolumn{2}{c|}{ Maximum } \\
\cline { 3 - 10 } & & Before & After & Before & After & Before & After & Before & After \\
\hline 1991 & 15 & -0.1385 & 0.1422 & 0.099 & 0.180 & -0.376 & -0.422 & -0.011 & 0.326 \\
\hline $1996 \mathrm{a}$ & 15 & -0.0420 & 0.3278 & 0.239 & 0.288 & -0.559 & -0.116 & 0.404 & 0.921 \\
\hline $1996 \mathrm{~b}$ & 15 & -0.0571 & 0.3162 & 0.338 & 0.413 & -0.483 & -0.222 & 0.707 & 1.486 \\
\hline 2008 & 15 & -0.1478 & 0.1946 & 0.383 & 0.476 & -0.914 & -0.779 & 0.427 & 0.847 \\
\hline 2014 & 15 & -0.1063 & 0.0429 & 0.203 & 0.152 & -0.428 & -0.250 & 0.127 & 0.290 \\
\hline 2018 & 15 & -0.0013 & 0.2000 & 0.454 & 0.498 & -0.304 & -0.226 & 1.593 & 1.849 \\
\hline $\begin{array}{c}\text { All } \\
\text { elections }\end{array}$ & $\mathbf{9 0}$ & $\mathbf{- 0 . 0 8 2 2}$ & $\mathbf{0 . 2 0 4 0}$ & $\mathbf{0 . 3 0 5}$ & $\mathbf{0 . 3 6 5}$ & $\mathbf{0 . 9 1 4}$ & $\mathbf{- 0 . 7 7 9}$ & $\mathbf{1 . 5 9 3}$ & $\mathbf{1 . 8 4 9}$ \\
\hline
\end{tabular}

Here, the means of abnormal returns representing the general motive of the investors are 0.0822 or, $-8.22 \%$ before all the elections and 0.2040 or, $20.40 \%$ after all the elections. It also shows that the mean of abnormal returns after election was always higher than the mean of abnormal returns before election in each election. It's evident that the stock market performs worse before the election and does better after the election through considering abnormal returns. The standard deviation, minimum and maximum limits of the data also describe the findings.

Table 5. Descriptive Statistics of the Index Returns

\begin{tabular}{|c|c|c|c|c|c|c|c|c|c|}
\hline \multirow{2}{*}{ Election } & \multirow{2}{*}{ Obs } & \multicolumn{2}{|c}{ Mean } & \multicolumn{2}{c|}{$\begin{array}{c}\text { Standard } \\
\text { Deviation }\end{array}$} & \multicolumn{2}{c|}{ Minimum } & \multicolumn{2}{c|}{ Maximum } \\
\cline { 2 - 10 } & & Before & After & Before & After & Before & After & Before & After \\
\hline 1991 & 15 & 0.0002 & 0.0026 & 0.001 & 0.007 & -0.002 & -0.001 & 0.003 & 0.027 \\
\hline $1996 \mathrm{a}$ & 15 & 0.0008 & 0.0033 & 0.007 & 0.005 & -0.012 & -0.006 & 0.019 & 0.011 \\
\hline $1996 \mathrm{~b}$ & 15 & 0.0019 & 0.0046 & 0.007 & 0.011 & -0.015 & -0.016 & 0.011 & 0.032 \\
\hline 2008 & 15 & 0.0014 & 0.0032 & 0.016 & 0.024 & -0.039 & -0.029 & 0.030 & 0.070 \\
\hline 2014 & 15 & -0.0002 & 0.0066 & 0.007 & 0.006 & -0.009 & -0.006 & 0.014 & 0.014 \\
\hline 2018 & 15 & -0.0014 & 0.0034 & 0.002 & 0.008 & -0.005 & -0.008 & 0.002 & 0.024 \\
\hline $\begin{array}{c}\text { All } \\
\text { elections }\end{array}$ & $\mathbf{9 0}$ & $\mathbf{0 . 0 0 0 4}$ & $\mathbf{0 . 0 0 3 9}$ & $\mathbf{0 . 0 0 8}$ & $\mathbf{0 . 0 1 2}$ & $\mathbf{- 0 . 0 3 9}$ & $\mathbf{- 0 . 0 2 9}$ & $\mathbf{0 . 0 3 0}$ & $\mathbf{0 . 0 7 0}$ \\
\hline
\end{tabular}

The descriptive statistics of broad index returns represented as whole market scenario shown on Table 5 indicate that differences between the means of the index returns of before and after each general election are very high, the standard deviations of the returns in case of the after elections are higher than the index returns of before elections in most cases. The minimum and maximum values have huge differences representing high volatilities due to election effects. The 
means of index returns representing whole market scenario are -0.0004 or, $-0.04 \%$ before all the elections and 0.0039 or, $0.39 \%$ after all the elections.

It also shows that the mean of index returns after election was always higher than the means of index returns before election in each election. It's evident that the stock market performs worse before the election and does better after the election under whole market scenario too. The standard deviation, minimum and maximum limits of the data also summarize the findings.

\section{Graphical Representation of the CARs and CIRs}

The Cumulative Abnormal Returns (CARs) and the Cumulative Index Returns (CIRs) provide the understanding of the trends of the abnormal returns and the index returns. The trends of CARs and CIRs with graphical representation are shown below:
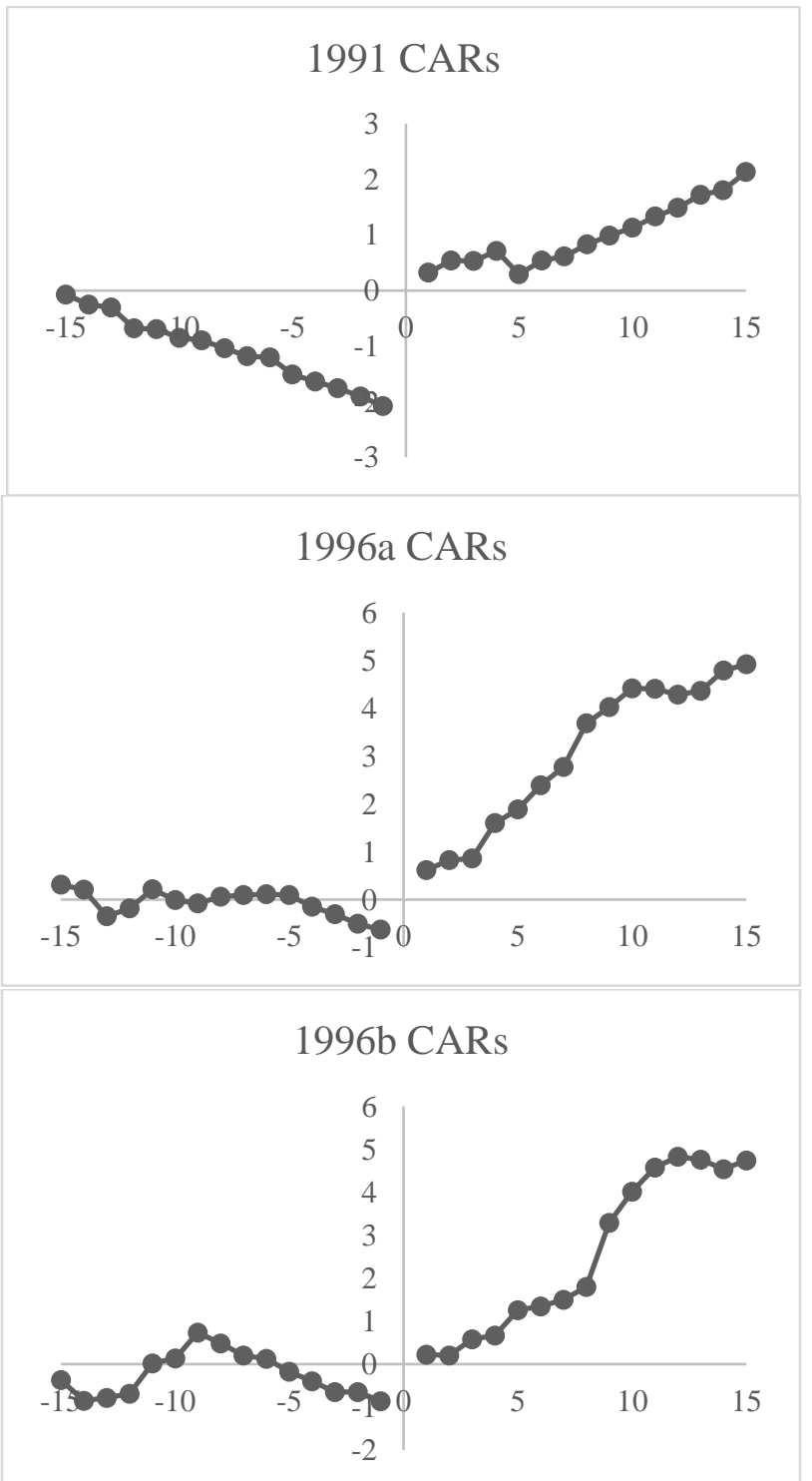

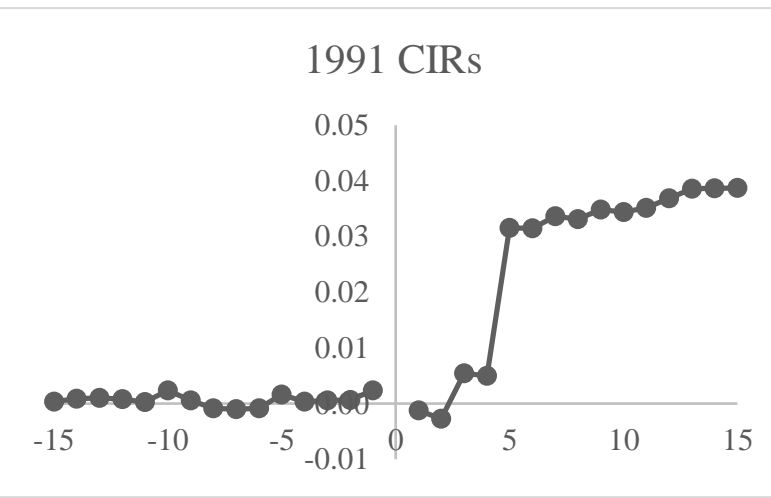

1996a CIRs
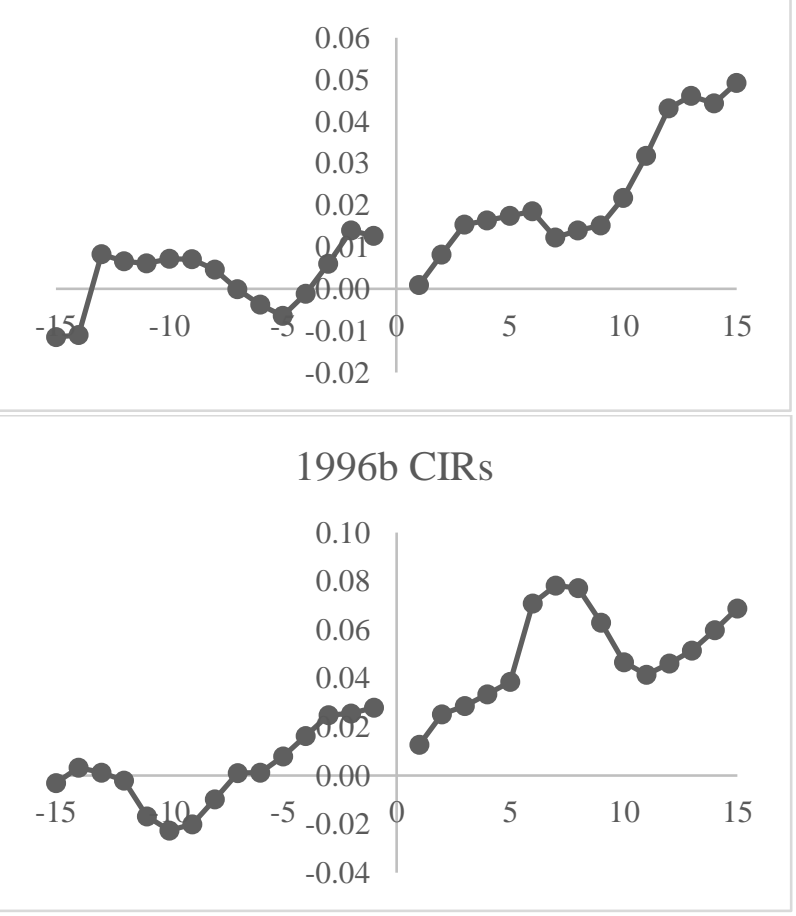


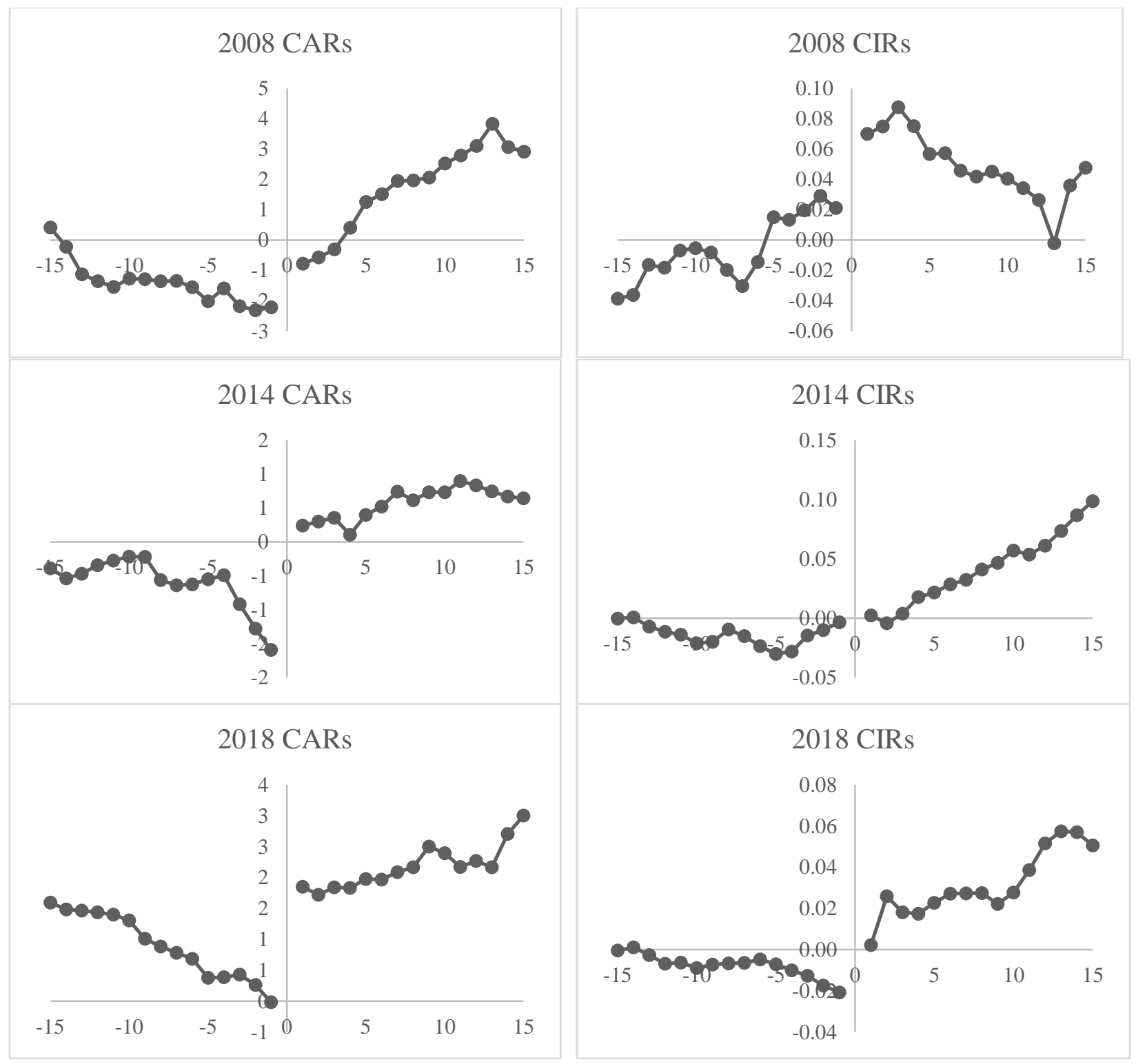

Figure 1. Trends of the curves of CARs and CIRs as per each election

In each of the charts shown on Figure 1, left side of vertical line shows the cumulative returns for the previous fifteen trading days of election and right side of vertical line shows the cumulative returns for the after fifteen trading days of election. Except the chart of $2008 \mathrm{CIRs}$, all the curves shown on Figure 1 indicate the gradual decline in cumulative returns before the elections and the gradual increase in cumulative returns after the elections. It's true for both the cumulative abnormal returns and cumulative index returns. Thus, it's an evidence of the significant impact of election on stock returns in Bangladesh from both the portfolio motive of the investors and the whole market scenario.

\section{Paired t-Test results for Abnormal Returns and Index Returns}

The paired t-test results of the abnormal returns in Table 6 show that there exist significant differences between the means of the returns of before and after days of all the elections. It also 
proves that in the overall case of test analysis, there exist significant difference between the means. Thus, the null hypothesis could be rejected. It means the average of abnormal returns before the election get changed after the election.

Table 6. Paired t-Test Results

\begin{tabular}{|c|c|c|c|c|}
\hline \multirow{2}{*}{ Election } & \multicolumn{2}{|c|}{ Paired t-test (Abnormal Returns) } & \multicolumn{2}{c|}{ Paired t-test (Index Returns) } \\
\cline { 2 - 5 } & $\mathrm{t}$ value & $\begin{array}{c}\text { Two-tailed p value } \\
(90 \% \text { confidence interval) }\end{array}$ & $\mathrm{t}$ value & $\begin{array}{c}\text { Two-tailed p value } \\
(90 \% \text { confidence interval) }\end{array}$ \\
\hline 1991 & $-4.5413^{*}$ & 0.001 & -1.2721 & 0.224 \\
\hline $1996 \mathrm{a}$ & $-5.5357^{*}$ & 0.000 & -1.2396 & 0.236 \\
\hline $1996 \mathrm{~b}$ & $-2.6801^{*}$ & 0.018 & -0.675 & 0.511 \\
\hline 2008 & $-1.8596^{*}$ & 0.084 & -0.1953 & 0.848 \\
\hline 2014 & $-2.5085^{*}$ & 0.025 & $-3.4409^{*}$ & 0.004 \\
\hline 2018 & $-3.2762^{*}$ & 0.006 & $-2.3683^{*}$ & 0.033 \\
\hline $\begin{array}{c}\text { All } \\
\text { elections }\end{array}$ & $\mathbf{- 6 . 5 8 3 9 *}$ & $\mathbf{0 . 0 0 0}$ & $\mathbf{- 2 . 0 0 4 1 *}$ & $\mathbf{0 . 0 4 8}$ \\
\hline
\end{tabular}

Note: Here '*' indicates significant

The paired t-test results of the index returns shown on Table 6 show that except for 1991, 1996a, 1996b, and 2008 general elections, all the other elections showed significant relationship between general elections and stock market movements. The test showed that in the overall case of test analysis, there existed significant difference between the means. Thus, here the null hypothesis could be rejected too.

The way of justification as like the findings through analyzing abnormal returns and the proper reasoning behind the acceptance of null hypothesis in 1991, 1996a, 1996b, and 2008 individual general election under index returns are that the DSEX index was getting the lower category and poor quality of stocks offsetting the real moves that were faced by the stocks chosen for calculating abnormal returns thus veiling the true information.

\section{F-Test results for Abnormal Returns and Index returns}

The F-test is used for checking the hypothesis of finding if there exist any significant differences between the variances of the data sets. If the hypothesis is proved, it can be concluded that there exists a relation between election and stock returns.

Table 7. F-Test Results

\begin{tabular}{|c|c|c|c|c|}
\hline \multirow{2}{*}{ Election } & \multicolumn{2}{|c|}{ F Test (Abnormal Returns) } & \multicolumn{2}{c|}{ F Test (Index Returns) } \\
\cline { 2 - 5 } & F value & $\begin{array}{c}\mathrm{p} \text { value }(90 \% \\
\text { confidence interval) }\end{array}$ & F value & $\begin{array}{c}\mathrm{p} \text { value }(90 \% \\
\text { confidence interval) }\end{array}$ \\
\hline 1991 & $0.3024^{*}$ & 0.033 & $0.0303^{*}$ & 0.000 \\
\hline $1996 \mathrm{a}$ & 0.6896 & 0.496 & 2.3071 & 0.130 \\
\hline $1996 \mathrm{~b}$ & 0.6676 & 0.459 & $0.373^{*}$ & 0.075 \\
\hline 2008 & 0.647 & 0.425 & 0.4426 & 0.139 \\
\hline
\end{tabular}




\begin{tabular}{|c|c|c|c|c|}
\hline 2014 & 1.7902 & 0.288 & 1.3381 & 0.593 \\
\hline 2018 & 0.832 & 0.736 & $0.0789^{*}$ & 0.000 \\
\hline $\begin{array}{c}\text { All } \\
\text { elections }\end{array}$ & $\mathbf{0 . 7 0 1 5} *$ & $\mathbf{0 . 0 9 6}$ & $\mathbf{0 . 4 6 4 6}^{*}$ & $\mathbf{0 . 0 0 0}$ \\
\hline
\end{tabular}

Note: Here '*' indicates significant

The F-Test results of the abnormal returns in Table 7 show that there were significant differences of the variances between the datasets. Only 1991 election accepted the null hypothesis. The F-Test of the index returns show that there were significant differences of the variances between datasets. Only 1991, 1996b, and 2018 elections accepted the null hypothesis.

\section{Summary of All the Findings}

So, from the above scrutiny and effective analyses of t-tests and F-tests, it can be concluded that the null hypothesis is rejected and the alternative hypothesis is accepted. It means that there exists a relationship between the election and stock market returns in Bangladesh.

The study tested the stock returns and found that in every election time period, the stock prices have negative shift before the election while these have a direct opposite shift right after the election. The most election cases and the overall averages of the stock returns showed that the null hypothesis should be rejected. It has been assured with proper justification of charts and interpretations in the findings and interpretations. So, it can be summed into following key understanding and findings:

- In case of index returns represented overall market scenario, the impacts of election on stock market is not as strong as we see in the case of the abnormal returns generated from chosen twenty stocks.

- The reason behind this sloth sensitivity is that there exists lower categories of stocks in the market which have the tendency to move directly to the opposite to the market trend, thus causing an offsetting impact and leading to make the means loosely different.

- In Bangladesh, the general election has negative consequences before the election and a positive consequence after the election on the stock returns.

- The stock market confidence of the common investors is pretty low as they have a common tendency to sell off the securities in the fear of any political crisis or stock market mishaps.

Thus, it can be concluded from overall analysis that the null hypothesis is rejected and alternative hypothesis indicate that there exists a relation between general election and stock returns in Bangladesh.

\section{CONCLUSION}

The stock market of Bangladesh is a pre-emerging market considered by most of the economists. It has been developing for many years in a fluctuating way, which sometimes creates risk and opportunities for some of the intermediaries who understand the functions of stock market in a better way. To identify the impact of general elections on stock market performance in Bangladesh, the study has been conducted by considering six national elections held between 1991 and 2018. This is an event study based research and the stock returns of previous 15 days and after 15 days of each election have been taken into analysis to gauge the impact of the election effect on the returns. The statistical analyses of the study including descriptive statistics, t-tests, and F-tests found that the general election strongly influences both the abnormal returns 
representing the motive of general investors and index returns representing whole market scenario. The stock selection and industry selection criteria as a measurement of abnormal returns for the investment motive of general investors were made in such a way that made the stocks and industries to represent the stock market of Bangladesh from 1991 to 2018. The study has found some very interesting findings. To avoid any expectation loss, the investors should follow the trend and invest in stocks that are less susceptible to the election. The trend that has been observed in the study that the major stock prices or broad index tends to fall sharply before the election and goes up after the election. So, proper judgement should be made to take investment decision during this time.

\section{For Policymakers}

\section{RECOMMENDATIONS}

The government and respected authorities regarding monetary and fiscal policies should incorporate some valuable issues in their actions. The market should be under proper surveillance all around the year and the speculating firms and stocks should be controlled under special policies by Bangladesh Securities and Exchange Commission. The speculative firms should be properly selected and updated time to time as per their performances so that the people become cautious of their trading and actions at the time of election. The limitation of fluctuation of the stock prices for any particular listed companies should be properly defined. The violation of fluctuating limit should be chastised by the authority.

\section{For Common Investors and Financial Market Participants}

There has been existence of some unnecessary and poor stocks in the stock market which creates imbalance in the stock market movements and expectations. The situation aggravates when this stocks go out of the market by leaving the investors bare handed during the apprehensive days election So, these poor and volatile stocks should not be let to be invested in the stock market of Bangladesh beyond a certain limit during election.

The analysis of each individual election indicates that the stock prices of the market lead to go down before election and go up after election. Thus the common investors should not get panicked for selling the stocks right before the election time without any jurisdiction. They should wait and let the market recover after the election. It has been noticed from the common cases under the study that the recovery that takes place after the election is much higher than it was before the election. So, a holding strategy will surely benefit the common investors and financial market participants.

The election effect on Bangladesh's stock market should be added in literacy programs in national levels and higher secondary levels for educating the common investors about the stock market movements regarding parliamentary election days. The common investors should create such a diversified portfolio that will offset the probability of loss during elections.

Thus, the following of these recommendations can be of some improvement against the volatility of the stock price before and after the election and thus, lead to a stable stock market in Bangladesh.

\section{REFERENCES}

Anderson, H., Malone, C., \& Marshall, B. (2008). Investment returns under right- and left-wing governments in Australasia. Pacific-Basin Finance Journal, 16(3), 252-267. https://10.1016/j.pacfin.2007.06.002 
Bialkowski, J., Gottschalk, K., \& Wisniewski, T. (2007). Political orientation of government and stock market returns. Applied Financial Economics Letters, 3(4), 269-273. https://10.1080/17446540701222359

Booth, J., \& Booth, L. (2003). Is presidential cycle in security returns merely a reflection of business conditions?.Review Of Financial Economics, 12(2), 131-159. https://10.1016/s1058-3300(02)00061-7

Cahan, J., Malone, C. B., Powell, J. G., \& Choti, U. W. (2005). Stock market political cycles in a small, two-party democracy. Applied Economics Letters, 12(12), 735-740.

Dhaka Stock Exchange. (2019). Retrieved from https://dsebd.org/

Foerster, S., \& Schmitz, J. (1997). The Transmission of U.S. Election Cycles to International Stock Returns. Journal of International Business Studies, 28(1), 1-13. https://10.1057/palgrave.jibs.8490089

Gemmill, G. (1992). Political risk and market efficiency: tests based in British stock and options markets in the 1987 election. Journal of Banking \& Finance, 16(1), 211-231.

Gilson, R. J. \& Black, B. S. (1995). The Law and Finance of Corporate Acquisitions.

Haroon, J. (2020). Bangladesh economy to become 28th largest in 2030. The Financial Express. Retrieved from https://www.thefinancialexpress.com.bd/economy/bangladesh/bangladesh-economy-tobecome-28th-largest-in-2030-1609126443

Hensel, C. R., \& Ziemba, W. T. (1995). United States investment returns during Democratic and Republican administrations, 1928-1993. Financial Analysts Journal, 61-69.

Hung, L. (2011). The Presidential Election and the Stock Market in Taiwan.

Irungu, A. (2012). Informational content of general election results announcement at the Nairobi securities exchange (Master of Science in Finance). University of Nairobi.

Jensen, G., Mercer, J., \& Johnson, R. (1996). Business conditions, monetary policy, and expected security returns. Journal of Financial Economics, 40(2), 213-237. https://10.1016/0304-405x(96)89537-7

Kabiru, J., Ochieng, D., \& Kinyua, H. (2015). European Scientific Journal, 11(28), 435-460. Retrieved from http://erepository.uonbi.ac.ke/handle/11295/96060

Lehander, S., \& Lönnqvist, F. (2011). Parliamentary Elections" Impact on Stock Market Returns (Masters). Stockholm School of Economics. 
MacKinlay, A. (1997). Event Studies in Economics and Finance. Journal of Economic Literature, 35(1), 13-39. Retrieved from https://www.jstor.org/stable/2729691

Markowitz, H. (1952). Portfolio Selection. The Journal of Finance, 7(1), 77-91. Retrieved from https://www.jstor.org/stable/2975974

Menge, R., Mwangi, M., \& Kimani, J. (2014). Effect of elections on stock market returns at the Nairobi securities exchange. Prime Journal of Social Science, 3(6), 763-768. Retrieved from https://www.semanticscholar.org/paper/Effect-of-elections-on-stock-marketreturns-at-the-Menge-Mwangi/43d27ec294be258ee6092445da281de1b3ac8591

Niederhoffer, V., Gibbs, S., \& Bullock, J. (1970). Presidential Elections and the Stock Market. Financial Analysts Journal,26(2), 111-113. Retrieved from https://www.jstor.org/stable/4470664

Pantzalis, C., Stangeland, D., \& Turtle, H. (2000). Political elections and the resolution of uncertainty: The international evidence. Journal of Banking \& Finance, 24(10), 15751604. https://10.1016/s0378-4266(99)00093-X

Peel, D. \& Pope, P. (1983). General Election in the U.K. in the Post-1950 Period and the Behavior of the Stock Market, Investment Analysis 67, 4-10

Santa-Clara, P., \& Valkanov, R. (2003). The Presidential Puzzle: Political Cycles and the Stock Market. The Journal of Finance,58(5), 1841-1872. https://doi.org/10.1111/15406261.00590

The Financial Express. (2021). DSEX drops 100 points over lockdown fears. Retrieved from https://thefinancialexpress.com.bd/stock/dsex-drops-100-points-over-lockdown-fears1624791410

Vuchelen, J. (2003). Electoral systems and the effects of political events on the stock market: The Belgian case. Economics \& Politics, 15(1), 85-102.

\section{ACKNOWLEDGEMENTS}

The authors express their gratitude to Nausheen Rahman, Professor, Department of Finance, University of Dhaka and Md. Sajib Hossain CFA, Assistant Professor, Department of Finance, University of Dhaka for their expert advice and encouragement throughout the research.

\section{APPENDICES}

Appendix A: List of Abnormal Returns and Index Returns

\begin{tabular}{|c|c|c|c|c|c|c|c|c|c|c|c|c|}
\hline \multirow[t]{2}{*}{ Day } & \multicolumn{6}{|c|}{ Abnormal Returns } & \multicolumn{6}{|c|}{ Index Returns } \\
\hline & 1991 & 1996a & 1996b & 2008 & 2014 & 2018 & 1991 & 1996a & 1996b & 2008 & 2014 & 2018 \\
\hline-15 & -0.075 & 0.313 & -0.367 & 0.413 & -0.388 & 1.593 & 0.000 & -0.012 & -0.003 & -0.039 & 0.000 & 0.000 \\
\hline-14 & -0.174 & -0.103 & -0.483 & -0.626 & -0.151 & -0.110 & 0.001 & 0.001 & 0.006 & 0.002 & 0.001 & 0.001 \\
\hline-13 & -0.056 & -0.559 & 0.065 & -0.914 & 0.068 & -0.019 & 0.000 & 0.019 & -0.002 & 0.020 & -0.008 & -0.004 \\
\hline-12 & -0.376 & 0.165 & 0.096 & -0.226 & 0.127 & -0.029 & 0.000 & -0.002 & -0.003 & -0.002 & -0.004 & -0.004 \\
\hline
\end{tabular}




\begin{tabular}{|c|c|c|c|c|c|c|c|c|c|c|c|c|}
\hline-11 & -0.011 & 0.404 & 0.707 & -0.190 & 0.068 & -0.038 & -0.001 & 0.000 & -0.015 & 0.011 & -0.002 & 0.001 \\
\hline-10 & -0.162 & -0.226 & 0.115 & 0.276 & 0.061 & -0.092 & 0.002 & 0.001 & -0.006 & 0.002 & -0.007 & -0.003 \\
\hline-9 & -0.041 & -0.076 & 0.601 & -0.018 & -0.006 & -0.296 & -0.002 & 0.000 & 0.002 & -0.003 & 0.001 & 0.002 \\
\hline-8 & -0.147 & 0.139 & -0.250 & -0.067 & -0.343 & -0.126 & -0.001 & -0.003 & 0.010 & -0.012 & 0.010 & 0.001 \\
\hline-7 & -0.139 & 0.042 & -0.279 & 0.007 & -0.076 & -0.103 & 0.000 & -0.005 & 0.011 & -0.011 & -0.006 & 0.000 \\
\hline-6 & -0.025 & 0.012 & -0.084 & -0.202 & 0.015 & -0.097 & 0.000 & -0.004 & 0.000 & 0.016 & -0.009 & 0.002 \\
\hline-5 & -0.303 & -0.014 & -0.291 & -0.467 & 0.074 & -0.304 & 0.003 & -0.003 & 0.007 & 0.030 & -0.007 & -0.002 \\
\hline-4 & -0.130 & -0.248 & -0.229 & 0.427 & 0.060 & 0.006 & -0.001 & 0.005 & 0.009 & -0.002 & 0.002 & -0.003 \\
\hline-3 & -0.116 & -0.156 & -0.250 & -0.588 & -0.428 & 0.041 & 0.000 & 0.007 & 0.009 & 0.006 & 0.014 & -0.003 \\
\hline-2 & -0.154 & -0.197 & -0.001 & -0.131 & -0.356 & -0.165 & 0.000 & 0.008 & 0.001 & 0.009 & 0.005 & -0.005 \\
\hline-1 & -0.170 & -0.125 & -0.208 & 0.091 & -0.317 & -0.281 & 0.002 & -0.001 & 0.002 & -0.008 & 0.007 & -0.003 \\
\hline 0 & - & - & - & - & - & - & - & - & - & - & - & - \\
\hline 1 & 0.325 & 0.616 & 0.222 & -0.779 & 0.242 & 1.849 & -0.001 & 0.001 & 0.013 & 0.070 & 0.002 & 0.002 \\
\hline 2 & 0.217 & 0.208 & -0.018 & 0.211 & 0.059 & -0.128 & -0.001 & 0.007 & 0.013 & 0.005 & -0.006 & 0.024 \\
\hline 3 & -0.007 & 0.040 & 0.377 & 0.264 & 0.056 & 0.119 & 0.008 & 0.007 & 0.003 & 0.013 & 0.008 & -0.008 \\
\hline 4 & 0.180 & 0.736 & 0.085 & 0.716 & -0.250 & -0.011 & 0.000 & 0.001 & 0.005 & -0.012 & 0.014 & -0.001 \\
\hline 5 & -0.422 & 0.290 & 0.595 & 0.847 & 0.290 & 0.144 & 0.027 & 0.001 & 0.005 & -0.018 & 0.004 & 0.005 \\
\hline 6 & 0.247 & 0.503 & 0.081 & 0.251 & 0.124 & -0.009 & 0.000 & 0.001 & 0.032 & 0.001 & 0.007 & 0.004 \\
\hline 7 & 0.075 & 0.375 & 0.154 & 0.436 & 0.220 & 0.122 & 0.002 & -0.006 & 0.007 & -0.012 & 0.004 & 0.000 \\
\hline 8 & 0.221 & 0.921 & 0.303 & 0.026 & -0.126 & 0.079 & -0.001 & 0.002 & -0.001 & -0.004 & 0.009 & 0.000 \\
\hline 9 & 0.152 & 0.336 & 1.486 & 0.088 & 0.118 & 0.337 & 0.002 & 0.001 & -0.014 & 0.003 & 0.006 & -0.005 \\
\hline 10 & 0.142 & 0.394 & 0.731 & 0.469 & 0.000 & -0.107 & 0.000 & 0.007 & -0.016 & -0.005 & 0.010 & 0.006 \\
\hline 11 & 0.205 & -0.016 & 0.561 & 0.268 & 0.162 & -0.226 & 0.001 & 0.010 & -0.005 & -0.006 & -0.003 & 0.011 \\
\hline 12 & 0.158 & -0.116 & 0.249 & 0.312 & -0.063 & 0.102 & 0.002 & 0.011 & 0.005 & -0.008 & 0.008 & 0.013 \\
\hline 13 & 0.230 & 0.078 & -0.069 & 0.724 & -0.089 & -0.105 & 0.002 & 0.003 & 0.005 & -0.029 & 0.012 & 0.006 \\
\hline 14 & 0.083 & 0.425 & -0.222 & -0.769 & -0.075 & 0.541 & 0.000 & -0.002 & 0.008 & 0.038 & 0.013 & 0.000 \\
\hline 15 & 0.326 & 0.127 & 0.207 & -0.144 & -0.026 & 0.294 & 0.000 & 0.005 & 0.009 & 0.012 & 0.012 & -0.006 \\
\hline
\end{tabular}

\section{Copyrights}

Copyright for this article is retained by the author(s), with first publication rights granted to the journal. This is an open-access article distributed under the terms and conditions of the Creative Commons Attribution license (http://creativecommons.org/licenses/by/4.0) 